\title{
Penambahan Larutan Daun Kersen (Muntingia calabura L.) dalam Pakan untuk Mencegah Penyakit Edwarsiliosis pada Ikan Jambal Siam (Pangasianodon hypophthalmus)
}

\author{
Addition Solution of Cherry Leaves (Muntingia calabura L.) in Feed to Prevent \\ Edwarsiliosis Disease in Striped Catfish (Pangasianodon hypophthalmus)
}

\author{
Dharga Mufti $\mathrm{Jr}^{{ }^{1 *}}$, Iesje Lukistyowati ${ }^{1}$, Morina Riauwaty ${ }^{1}$ \\ ${ }^{1}$ Jurusan Budidaya Perairan, Fakultas Perikanan dan Kelautan, Universitas Riau \\ Kampus Bina Widya Jl. HR. Soebrantas Km 12.5, Pekanbaru, 28293 \\ email:dhargamufti.jr@gmail.com
}

(Received: 08Januari 2022; Accepted: 28 Februari 2022)

\begin{abstract}
ABSTRAK
Penelitian ini dilaksanakan pada bulan Desember 2019 s/d Februari 2020 bertempat di Laboratorium Parasit dan Penyakit Ikan Fakultas Perikanan dan Kelautan Universitas Riau. Penelitian ini bertujuan untuk mengetahui pengaruh penambahan larutan daun kersen (Muntingia calabura $L$.) terhadap gambaran leukosit dan mendapatkan dosis terbaik penambahan larutan daun kersen ke dalam pakan. Metode yang digunakan adalah metode eksperimen dengan menggunakan Rancangan Acak Lengkap (RAL) dengan lima taraf perlakuan yaitu $\mathrm{Kn}=$ Kontrol negatif (pemberian pakan tanpa penambahan kersen), $\mathrm{Kp}=\mathrm{Kontrol}$ positif (pemberian pakan tanpa penambahan kersen), P1= penambahan larutan daun kersen dengan dosis $1 \mathrm{~mL} / \mathrm{kg}$ Pakan, $\mathrm{P} 2=$ penambahan larutan daun kersen dengan dosis $2 \mathrm{~mL} / \mathrm{kg}$ pakan dan $\mathrm{P} 3=$ penambahan larutan daun kersen dengan dosis $3 \mathrm{~mL} / \mathrm{kg}$ pakan. Hasil penelitian menunjukkan larutan daun kersen berpengaruh nyata terhadap gambaran leukosit ikan jambal siam (Pangasianodon. hypophthalmus) dilihat dari adanya peningkatan total leukosit, diferensiasi leukosit, dan aktivitas fagositosis $(\mathrm{P}<0,05)$. Dosis terbaik terdapat pada perlakuan P3 $(3 \mathrm{~mL} / \mathrm{kg}$ pakan) dengan rata-rata jumlah leukosit $9,38 \times 10^{4} \mathrm{sel} / \mathrm{mm}^{3}$, aktivitas fagositik sebesar $31,67 \%$, dan tingkat kelulushidupan mencapai $86,67 \%$. Sedangkan persentase limfosit $83,00 \%$, monosit $9,00 \%$ dan neutrofil $8,00 \%$.
\end{abstract}

Kata Kunci : Leukosit, Muntingia calabura, Pangasianodon hypopthalmus

\begin{abstract}
This research was conducted from December 2019 to February 2020 at the Laboratory of Parasites and Fish Diseases, Faculty of Fisheries and Marine, Universitas Riau. This study aims to analyze the addition of cherry leaf solution (Muntingia calabura L.) and get the best dose of adding cherry leaf solution (M. calabura L) to the feed. The method used was an experimental method with a Completely Randomized Design (CRD) consisting of one factor with five treatment levels which included; $\mathrm{Kn}=$ negative control (without the addition of cherry leaf), $\mathrm{Kp}=$ positive control (without adding cherry leaf and infected with E.tarda bacteria), P1 = addition of cherry leaf solution with a dose of $1 \mathrm{~mL} / \mathrm{kg}$ of feed, P2 = addition of a solution of cherry leaves with a dose of $2 \mathrm{~mL} / \mathrm{kg}$ of feed, and P3 = addition of a solution of cherry leaves with a dose of $3 \mathrm{~mL} / \mathrm{kg}$ of feed. The leukocyte parameters measured were total leukocytes, leukocyte differentiation and phagocytic activity. The results showed that the addition of cherry leaf solution to feed affected the image of leukocytes of striped catfish $(P$. hypophthalmus) $(\mathrm{P}<0,05)$. The best dose is in the treatment of $\mathrm{P} 3$ ( $3 \mathrm{~mL} / \mathrm{kg}$ of feed) with average total leukocytes $9.38 \times 10^{4}$ cells $/ \mathrm{mm}^{3}$, the phagocytic activity was $31.67 \%$, lymphocytes was $83.00 \%$, monocytes $9,00 \%$ and $8.00 \%$ neutrophils, and the survival rate reached $86.67 \%$.
\end{abstract}

Keyword : Leucocyte, Muntingia calabura, Pangasianodon hypopthalmus 


\section{Pendahuluan}

Ikan jambal siam (Pangasianodon hypophthalmus) merupakan ikan yang banyak digemari masyarakat khususnya di daerah Riau. Konsumsi ikan jambal perkapita cenderung meningkat tiap tahunnya yakni mencapai 21,9\% terhitung dari tahun 2014 hingga tahun 2017 dengan preferensi produk ikan segar sebanyak $76 \%$. Untuk memenuhi permintaan tersebut, maka kegiatan budidaya perlu ditingkatkan (KKP, 2018).

Namun dalam membudidayakan ikan jambal siam dengan sistem budidaya intensif yang tidak ditangani dengan baik dapat menimbulkan dampak negatif akibat masalah lingkungan dan penyebaran penyakit. Salah satu masalah yang kerap dihadapi pada usaha budidaya adalah serangan penyakit bakterial.

Penyakit Edwardsiellosis sering menyerang ikan jambal siam yang disebabkan oleh bakteri Edwardsiella tarda. Penyakit Edwardsiellosis dikenal sebagai penyakit utama pada budidaya jenis catfish dan dikenal sebagai: "Emphysemateous Putrefacive Disease of Catfish" (EPDC). Perkembangan E.tarda umumnya sangat lambat. Salah satu faktor penyebab terjadinya infeksi E.tarda adalah karena ikan stres, terutama akibat tingginya padat tebar menjelang panen, kondisi kualitas air yang jelek, dan tingginya kandungan bahan organik. Penyakit edwardsiellosis, dapat menyebabkan kematian pada ikan habitat air tawar maupun air laut (Thune et al., 1993).

Penanggulangan penyakit yang disebabkan oleh bakteri selama ini sering menggunakan antibiotik. Hal ini disebabkan antibiotik memiliki beberapa kelebihan diantaranya mudah didapat, efektivitas lebih tinggi dan harga terjangkau. Namun penggunaan antibiotik dalam budidaya ikan memiliki beberapa efek samping yang merugikan diantaranya antibiotik dapat menimbulkan resisten pada bakteri patogen yang ada di perairan, dapat mencemari lingkungan perairan, juga akan berpengaruh terhadap manusia yang mengonsumsi ikan tersebut.

Untuk mengatasi permasalahan tersebut, perlu dilakukan penggunaan imunostimulan dari bahan alami yang terbukti efektif dan aman untuk manusia dan lingkungan (Sukenda et al., 2008) salah satu bahan alami yang dapat dijadikan imunostimulan adalah daun kersen yang diharapkan dapat meningkatkan sistem pertahanan tubuh pada ikan jambal siam.

Menurut Rosidah et al. (2018) pengobatan benih ikan nila yang terinfeksi bakteri Aeromonas hydrophila menggunakan ekstrak daun kersen (Muntingia calabura) dengan metode perendaman pada konsentrasi $60 \mathrm{ppm}$ dapat menghasilkan sintasan benih ikan nila sebesar $81,67 \%$.

Hasil penelitian Zebua et al. (2019) menunjukkan bahwa, ekstrak daun kersen mampu menghambat bakteri E. tarda hingga dosis 700 ppm dengan diameter zona hambat sebesar 6,14 mm. Dosis minimum Inhibitory concentration (MIC) ekstrak daun kersen 700 ppm dengan rerata jumlah koloni bakteri 261,66 CFU/mL. Dosis LD 50 ekstrak daun kersen untuk ikan lele dumbo (Clarias gariepinus) adalah 720,06 ppm. Berdasarkan uraian di atas, maka penulis tertarik untuk melakukan penelitian tentang penambahan larutan daundicampur dalam pakan untuk mecegah Edwardsilliosis pada ikan jambal siam dilihat dari profil leukosit.

Tujuan penelitian adalah untuk menganalisis pengaruh penambahan larutan daun kersen terhadap gambaran leukosit dan mendapatkan dosis terbaik penambahan larutan daun kersen untuk mencegah Edwardsilliosis.

\section{Metode Penelitian}

\subsection{Waktu dan Tempat}

Penelitian ini dilaksanakan selama 46 hari yaitu pada tanggal 22 Desember 2019 sampai dengan 5 Februari 2020 di Laboratorium Parasit dan Penyakit Ikan Fakultas Perikanan dan Kelautan Universitas Riau.

\subsection{Metode Penelitian}

Metode yang digunakan dalam penelitian ini adalah metode eksperimen dengan menggunakan rancangan acak lengkap (RAL) satu faktor dengan 5 kali perlakuan dan 3 kali ulangan. Perlakuan yang diterapkan dalam penelitian ini adalah:

$\mathrm{Kn}=$ pemberian pakan tanpa 
penambahan kersen dan tidak di uji tantang dengan E.tarda)
$\mathrm{Kp}=$ pemberian pakan tanpa penambahan kersen dan di uji tantang dengan E.tarda

$\mathrm{P} 1=$ Pemberian pakan dengan penambahan kersen $1 \mathrm{~mL} / \mathrm{kg}$ pakan

$\mathrm{P} 2=$ Pemberian pakan dengan penambahan kersen $2 \mathrm{~mL} / \mathrm{kg}$ pakan

$\mathrm{P} 3=$ Pemberian pakan dengan penambahan kersen $3 \mathrm{~mL} / \mathrm{kg}$ pakan

\subsection{Prosedur Penelitian}

\subsubsection{Persiapan Wadah}

Wadah pemeliharaan yang digunakan adalah akuarium berukuran $40 \times 30 \times 30 \mathrm{~cm}^{3}$ sebanyak 15 unit. Sebelum digunakan akuarium terlebih dahulu dibersihkan. Kemudian akuarium diisi air sampai penuh dan diberi larutan $\mathrm{KMnO}_{4} \quad$ (Kalium Permanganat) selama 24 jam agar akuarium steril dari mikroorganisme patogen Setelah itu akuarium dibersihkan kemudian dikeringkan. Masing-masing akuarium diisi dengan air setinggi $25 \mathrm{~cm}$ dengan volume 30 L. Setelah semua wadah terisi air, pemasangan aerasi sebanyak 1 unit per wadah, guna meningkatkan oksigen telarut biarkan selama 1 hari.

\subsubsection{Pembuatan Larutan Daun Kersen}

Daun kersen yang digunakan pada daun ke 4-10 dari pucuk setiap tangkai, daun ini sekiranya tidak terlalu tua dan tidak terlalu muda. Daun kersen yang sudah dipilih, dicuci dengan air mengalir kemudian dikering anginkan selama \pm 30 menit di atas wadah berupa nampan. Setelah kering daun kersen dihaluskan dengan blender tanpa menggunakan air. Hasil blender daun kersen diperas menggunakan kain kasa steril. Hasil perasan disaring kembali menggunakan kertas saring Whatman nomor $42 \mu \mathrm{m}$ sehingga didapatkan larutan stok $100 \%$. Larutan stok ini siap digunakan untuk penelitian sesuai dengan dosis yang ditetapkan.

\subsubsection{Pembuatan Pakan yang Mengandung Larutan Daun kersen}

Terlebih dahulu lakukan perhitungan formulasi pakan yang akan dibuat, diharapkan kandungan pakan mengandung $35 \%$ protein. Kemudian bahan-bahan yang digunakan ditimbang sesuai formulasi. Pencampuran bahan dilakukan secara bertahap, mulai dari jumlah yang paling sedikit hingga yang paling banyak agar campuran menjadi homogen. Sedangkan larutan daun kersen dicampurkan dengan menggunakan air hangat dengan suhu $30^{\circ} \mathrm{C}$ lalu diaduk bersama bahan pakan lainnya. Pelet dicetak dengan alat pencetak pelet, kemudian pelet dikeringkan dengan penjemuran di bawah sinar matahari.

\subsubsection{Pemeliharaan Ikan}

Ikan sebelum diberi perlakuan diaklimatisasi terlebih dahulu selama 3 hari agar tidak stres dan dapat beradaptasi dengan pakan dan lingkungan. Kemudian ikan diukur dan ditimbang berat tubuhnya sebelum perlakuan, setelah itu dimasukkan ke wadah yang telah disiapkan. Ikan mulai diberi perlakuan dengan memberikan pakan sesuai dengan dosis yang telah ditetapkan. Pakan diberikan sebanyak $10 \%$ dari bobot biomasa pada pukul 08.00 WIB, 12.00 WIB dan 17.00 WIB selama 46 hari. Untuk mengetahui pertumbuhan ikan dilakukan sampling setiap 15 hari sekali.

\subsubsection{Pengambilan Darah}

Syringe dan mikrotube dibasahi dengan EDTA $10 \%$. Darah diambil menggunakan syringe $1 \mathrm{~mL}$ pada bagian vena caudalis dekat linea lateralis dan dimasukkan dalam mikrotube yang sudah dibasahi dengan EDTA 10\%.

\subsection{Parameter yang Diamati \\ 2.4.1. Pengamatan Gejala Klinis}

Pengamatan gejala klinis dilakukan setiap jam selama 14 hari setelah pascainfeksi E. tarda. Gejala yang diamati adalah perubahan morfologi dan tingkah laku ikan. Perubahan morfologi yang terjadi, seperti pendarahan pada pangkal sirip, sirip geripis, produksi lendir yang berlebihan dan diikuti dengan timbulnya ulcer pada bagian bekas suntikan. Sedangkan perubahan tingkah laku ikan berenang tidak teratur dan respons terhadap pakan menurun. 


\subsubsection{Total Leukosit}

Sampel darah dihisap dengan pipet leukosit hingga skala 0,5 dan ditambah larutan Turk hingga garis 11. Selanjutnya dihomogenkan dengan cara menggoyangkan pipet membentuk angka delapan. Kemudian dibuang sebanyak dua tetes agar tidak ada gelembung udara.

Selanjutnya diteteskan pada kamar hitung haemositometer dan ditutup dengan cover glass. Selanjutnya diamati di bawah mikroskop dengan pembesaran 10 x 40 . Rumus perhitungan total leukosit sebagai berikut (Blaxhall dan Daisley, 1973):

\section{$\sum$ Leukosit $=\sum$ n $\times 50 \mathrm{sel} / \mathrm{mm}^{3}$}

Keterangan :

$\sum \mathrm{n}=$ Jumlah total leukosit pada 4 kotak besar

$50=$ Faktor pengenceran

\subsubsection{Diferensiasi Leukosit}

Sampel darah dibuat menjadi preparat ulas darah pada object glass lalu dikering anginkan, selanjutnya difiksasi dengan larutan metanol $95 \%$ selama 5 menit, setelah itu dibilas dengan akuades lalu dikering anginkan, dan dilanjutkan dengan pewarnaan Giemsa selama 15 menit, setelah itu dicuci dengan air mengalir, kemudian dikering anginkan. Selanjutnya preparat dapat diamati di bawah mikroskop dengan perbesaran 1000x. Jenis leukosit yang diamati adalah limfosit, neutrofil dan monosit.

\subsubsection{Aktivitas Fagositosis}

Sampel darah diambil sebanyak $50 \mu \mathrm{L}$ dan dimasukkan ke dalam mikrotube, setelah itu ditambahkan sebanyak $50 \mu \mathrm{L}$ suspensi bakteri Staphylococcus aereus dengan kepadatan $10^{7} \mathrm{sel} / \mathrm{mL}$. Kemudian suspensi tersebut dihomogenkan dan diinkubasi dalam suhu ruang selama 20 menit. Selanjutnya suspensi tersebut dibuat menjadi preparat ulas lalu dikering anginkan, selanjutnya difiksasi dengan larutan metanol selama 5 menit. Kemudian dilanjutkan dengan pewarnaan Giemsaselama 15 menit, setelah itu dibilas dengan akuades dan kembali dikering anginkan. Selanjutnya preparat dapat diamati di bawah mikroskop dengan perbesaran 1000x. Persentase sel fagositik dihitung dengan cara mengamati sel-sel yang memfagosit bakteri.

\subsubsection{Kelulushidupan Ikan}

Kelulushidupan ikan jambal siam yang diberi pakan mengandung larutan daun kersen selama 46 hari dihitung dengan rumus sebagai berikut (Effendie, 1979) :

$$
\mathrm{SR}=\frac{\sum \mathrm{Nt}}{\sum \mathrm{No}} \times 100 \%
$$

Keterangan :

$\mathrm{SR}=$ Kelulushidupan $(\%)$

$\mathrm{Nt}=$ Jumlah ikan akhir pemeliharaan

No $=$ Jumlah ikan awal pemeliharaan

\section{Hasil dan Pembahasan \\ 3.1. Gejala Klinis}

Pengamatan gejala klinis ikan uji selama 14 hari pascainfeksi dengan bakteri E.tarda menunjukkan perubahan tingkah laku dan perubahan morfologi pada ikan uji diantaranya adalah perubahan berenang yang mendekati aerasi, berenang tidak teratur, pergerakan renang melambat dan penurunan respon pakan, serta produksi lendir yang berlebih, warna tubuh yang memudar, terjadi peradangan pada tubuh, beberapa bagian tubuh ikan mengalami geripis perubahan pada mulut ikan berwarna merah serta adanya pembengkakan dan luka (ulcer) pada bekas suntikan.

Perlakuan kontrol positif (Kp) menunjukkan gejala berupa peradangan pada bagian mulut, sirip dada dan punggung, melanisasi bagian tubuh/perubahan warna tubuh lebih memucat (memudar), hemoragi yang ditandai dengan lesi kecil pada permukaan tubuh serta timbulnya ulcer (tukak) berongga semakin melebar dan bertambah dalam pada bagian linea lateralis disekitar sirip punggung. Hasil penelitian menunjukkan pada perlakuan $\mathrm{P}_{3}$ dosis larutan daun kersen $3 \mathrm{ml} / \mathrm{kg}$ pakan menunjukkan gejala klinis yang lebih ringan daripada pelakuan kontrol positif (Kp), $\mathrm{P}_{1}$ dan $\mathrm{P}_{2}$ yaitu gejala berupa inflamasi (peradangan) di beberapa bagian tubuh seperti pangkal ekor, sirip dada dan di bagian bekas suntikan pada 48 jam pascainfeksi, dan berangsur pulih secara parsial (masih terlihat gejala klinis) hingga akhir pengamatan. Hal ini dikarenakan daun kersen mempunyai aktivitas sebagai anti inflamasi (anti peradangan), aktivitas terhadap peptic ulcer, antibiotik, dan aktivitas anti kanker (Sumiati dan Adnyana, 2007). Lebih jelas dapat dilihat pada Gambar 1. 


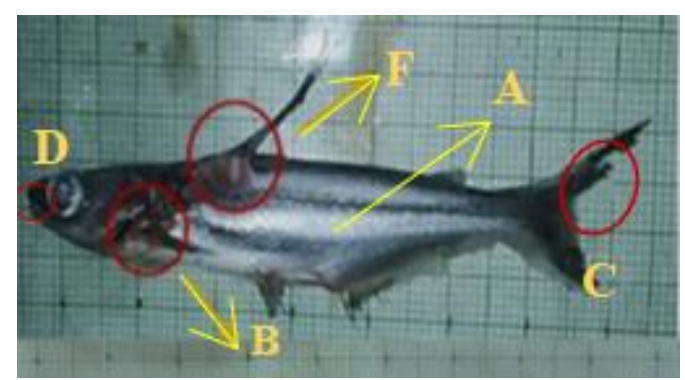

$\mathrm{Kp}$

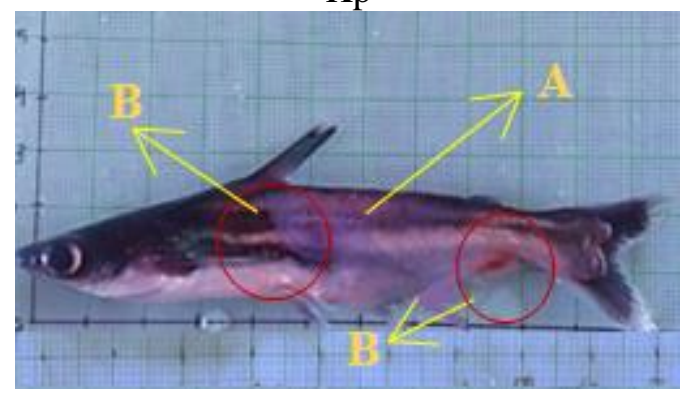

P2

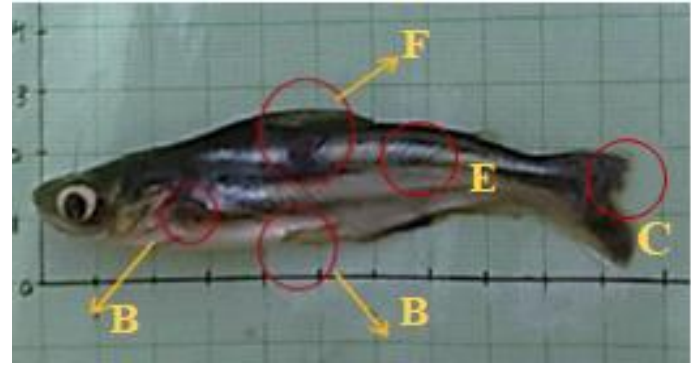

P1

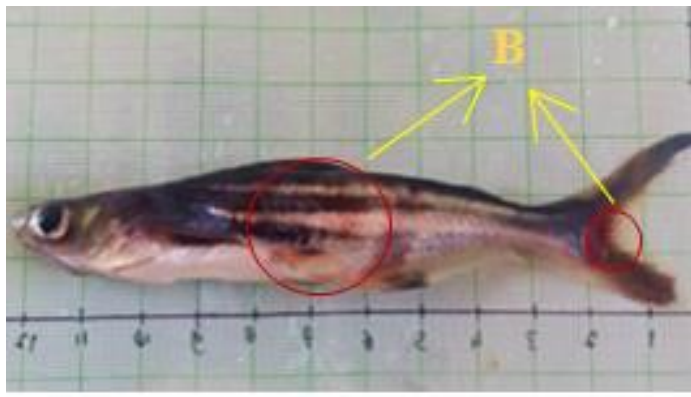

P3

Gambar 1. Gejala Klinis Ikan Jambal Siam Pasca Infeksi E. Tarda

Keterangan : (a) Warna tubuh memudar, (b) Terjadi peradangan berwarna merah di bagian tubuh, (c) Bagian ekor mengalami geripis, (d) Bagian mulut geripis dan berwarna merah kehitaman, (e) Luka bekas suntikan membengkak dan (f) adanya ulcer di beberapa bagian tubuh

\subsection{Total Leukosit Ikan Jambal Siam}

Hasil pengamatan total leukosit menunjukkan bahwa pemberian larutan daun kersen yang dicampur dalam pakan dapat meningkatkan total leukosit ikan jambal siam. Peningkatan jumlah leukosit pada ikan jambal siam yang diberi pakan mengandung larutan daun kersen dengan dosis yang berbeda selama 30 hari menunjukkan jumlah leukosit yang beragam. Jumlah leukosit yang terbanyak terdapat pada perlakuan P3 sebesar $8,92 \times 10^{4} \mathrm{sel} / \mathrm{mm}^{3}$ sedangkan yang terendah sebesar $8,37 \times 10^{4} . \mathrm{sel} / \mathrm{mm}^{3}$ pada perlakuan Kn (Gambar 2).

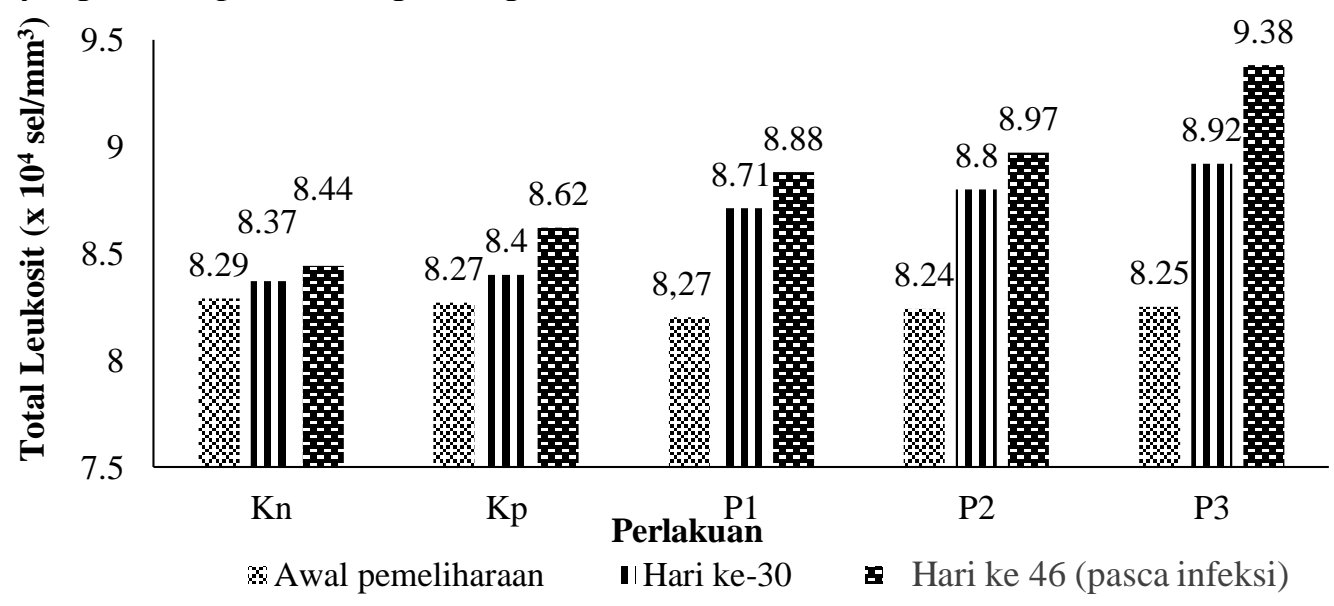

\section{Gambar 2. Total Leukosit $\left(x 10^{4} \mathrm{sel} / \mathrm{mm}^{3}\right)$ Ikan Jambal Siam Selama 46 hari Pemeliharaan}

Pemberian larutan daun kersen ini terlihat tidak membahayakan bagi ikan jambal siam karena jumlah leukosit masih berada dalam batas normal. Hal ini sesuai dengan pendapat Dontriska et al. (2014) yang mengemukakan bahwa ikan jambal siam normal jumlah leukositnya berkisar $8-10 \quad$ x $10^{4} \mathrm{sel} / \mathrm{mm}^{3}$. Berdasarkan uji analisis variansi (ANOVA) menunjukkan bahwa pemberian pakan yang ditambah larutan daun kersen memberikan pengaruh nyata $(\mathrm{P}<0,05)$ terhadapat total leukosit ikan jambal siam. Dimana Kp 
berbeda nyata terhadap P1, P2 dan P3, namun $\mathrm{Kp}$ tidak berbeda nyata dengan $\mathrm{Kn}$. Meningkatnya leukosit pada ikan perlakuan ini diduga merupakan bentuk respon dari tubuh ikan terhadap adanya benda asing yang masuk kedalam tubuh. Benda asing ini berupa pemberian larutan daun kersen yang dicampurkan ke dalam pakan.

Senyawa aktif yang terkandung didalam daun kersen bersifat imunomodulator, yaitu senyawa yang dapat mengaktifkan dan meningkatkan sel pertahanan tubuh (Haki, 2009) seperti flavonoid, tanin dan saponin. Salah satu zat yang menjadi imunomodulator yakni saponin yang merupakan glikosida alami yang terikat dengan steroid alkaloid atau triterpena, mempunyai efek farmakologis seperti imunomodulator, antitumor, antiinflamasi, anti jamur, anti virus, hipoglikemik dan hipokolesterol (Robinson, 1995)

Kombinasi kandungan kimia alami dari daun kersen yang mengandung vitamin $\mathrm{C}$ serta vitamin A juga memberikan kontribusi dalam meningkatnya total leukosit darah. Vitamin A yang berperan dalam menstimulasi produksi dan maturasi limfosit (Linder, 1992) serta vitamin $\mathrm{C}$ yang berperan menstimulasi respon imun non spesifik, fagosit oleh neutrofil dan monosit (Jhonny et al., 2005).

Pasca uji tantang dengan bakteri E.tarda pada hari ke 46 jumlah leukosit juga mengalami peningkatan. Jumlah tertinggi terdapat pada perlakuan P3 sebesar 9,38 x $10^{4}$ $\mathrm{sel} / \mathrm{mm}^{3}$, sedangkan yang terendah terdapat pada perlakuan $\mathrm{Kp}$ sebesar 8,62 x $10^{4}$ sel $/ \mathrm{mm}^{3}$, sedang perlakuan $\mathrm{Kn}$ yang tidak di uji tantang dengan bakteri E.tarda leukositnya sebesar $8,44 \times 10^{4} \mathrm{sel} / \mathrm{mm}^{3}$. Hasil uji lanjut Newman-Keuls menunjukkan bahwa P3 berbeda nyata terhadap semua perlakuan, namun Kn tidak berbeda nyata terhadap Kp serta P1 tidak berbeda nyata terhadap P2.

Meningkatnya jumlah leukosit mengindikasikan bahwa sel monosit pada tubuh melakukan perlawanan terhadap bakteri E.tarda yang masuk kedalam tubuh ikan jambal siam. Hal ini sependapat dengan pernyataan Kresno (2001), bahwa tingginya sel leukosit merupakan refleksi keberhasilan sistem imunitas ikan dalam mengembangkan respons imunitas seluler (non spesifik) sebagai pemicu untuk respons kekebalan. Disisi lain, meningkatnya total leukosit juga dapat disebabkan oleh kondisi lingkungan yang memburuk, serta faktor stres. Kandungan lain dari daun kersen yang diduga juga memberikan pengaruh guna melemahkan serangan patogen yakni, tanin dan alkaloid. Tanin berfungsi sebagai antimikroba, adapun efek yang ditimbulkan melalui reaksi dengan membran sel, destruksi atau inaktivasi dari fungsi materi genetik (Ajizah, 2004). Sedangkan alkaloid bersifat antibakteri, mekanisme kerja dari alkaloid yaitu dengan mengganggu komponen penyusun peptidoglikan pada sel bakteri, sehingga lapisan dinding sel tidak dapat terbentuk secara utuh dan menyebabkan kematin pada sel bakteri (Darsana et al., 2012).

Pada perlakuan Kp ada peningkatan total leukosit pasca penginfeksiandengan bakteri E.tarda namun tidak naik secara signifikan. Kenaikan total leukosit menunjukkan adanya perlawanan tubuh terhadap zat asing, namun karena tidak adanya penambahan larutan daun kersen sebagai zat imunostimulus dalam pakan guna memacu efektifitas pembentukan sel leukosit. Patogen lebih cepat melemahkan tingkat kekebalan tubuh ikan. Ikan menjadi lebih rentan terinfeksi, sehingga menghambat fungsi kerja organ ginjal dan limfa dalam memproduksi leukosit sebagai pertahanan non spesifik. Sehingga banyak ikan Kp yang tidak dapat bertahan hidup melawan patogen E.tarda.

\subsection{Diferensiasi Leukosit}

Peningkatan persentase limfosit ikan jambal siam, dimana pada awal pemeliharaan berkisar 72,00-74,00\%, pada 30 hari pemeliharaan menjadi $72,00-80,00 \%$, dan pada 46 hari pemeliharaan persentase limfosit ikan jambal siam berkisar 69,00-83,00\%. Persentase limfosit ini masih dalam kisaran normal sesuai pendapat Preanger et al. (2016) dimana jumlah persentase rata-rata limfosit di dalam darah berkisar antara 71,12-83,88\% sedangkan Lukistyowati et al. (2007) mengemukakan, persentase normal limfosit ikan adalah 76-97,5\% Hasil pengamatan diferensiasi leukosit pada ikan jambal siam yang dipelihara dapat dilihat pada Tabel 1 .

Hasil uji statistik analisis variasi (ANAVA), menunjukkan bahwa setelah 46 hari pemeliharaan dengan pemberian pakan yang ditambah larutan daun kersen memberikan pengaruh nyata terhadapat persentase limfosit ikan jambal siam $(\mathrm{P}<0,05)$. 
Hasil uji lanjut Newman-Keuls menunjukkan bahwa P3 berbeda nyata terhadap Kn, Kp, P1, dan P2, tetapi Kn tidak memberikan perbedaan nyata terhadap P1 dan P2.

Tabel 1. Diferensiasi leukosit ikan jambal siam ( $P$. hypopthalmus) selama penelitian

\begin{tabular}{ccccc}
\hline Pengamatan & Perlakuan & \multicolumn{3}{c}{ Diferensiasi Leukosit } \\
\cline { 3 - 5 } & & Limfosit (\%) & Neutrofil (\%) & Monosit (\%) \\
\hline & Kn & 74,00 & 12,33 & 13,67 \\
Hari ke-1 & Kp & 72,33 & 12,67 & 15,00 \\
& P1 & 72,00 & 14,00 & 14,00 \\
& P2 & 72,00 & 13,33 & 14,67 \\
& P3 & 73,33 & 11,67 & 15,00 \\
\hline & Kn & $77,00 \pm 1,00^{\mathrm{bc}}$ & $12,67 \pm 1,52^{\mathrm{b}}$ & $10,33 \pm 1,52^{\mathrm{a}}$ \\
Hari ke-46 & $\mathrm{Kp}$ & $69,00 \pm 1,00^{\mathrm{a}}$ & $17,33 \pm 0,57^{\mathrm{c}}$ & $13,67 \pm 1,15^{\mathrm{b}}$ \\
(pasca infeksi & P1 & $75,33 \pm 2,08^{\mathrm{b}}$ & $13,33 \pm 1,52^{\mathrm{b}}$ & $11,33 \pm 0,57^{\mathrm{a}}$ \\
E.tarda) & P2 & $78,67 \pm 1,15^{\mathrm{c}}$ & $10,33 \pm 2,08^{\mathrm{ab}}$ & $11,00 \pm 1,00^{\mathrm{a}}$ \\
& P3 & $83,00 \pm 1,00^{\mathrm{d}}$ & $8,00 \pm 1,73^{\mathrm{a}}$ & $9,00 \pm 1,00^{\mathrm{a}}$ \\
\hline
\end{tabular}

Keterangan : Kn : Kontrol negatif; Kp : Kontrol positif; P1 : $1 \mathrm{~mL} / \mathrm{Kg} ; \mathrm{P} 2: 2 \mathrm{~mL} / \mathrm{Kg}$; P3: $3 \mathrm{~mL} / \mathrm{Kg}$.

Persentase limfosit terendah terdapat pada perlakuan $\mathrm{Kp}$ (pemberian pakan tanpa penambahan lart. kersen dan di uji tantang dengan E.tarda) sebesar $69,00 \%$. Penurunan limfosit pada perlakuan $\mathrm{Kp}$ diduga karena kondisi ikan dalam keadaan stress akibat masuknya bakteri $E$. tarda kedalam tubuh. Hal ini sesuai dengan pendapat Bijanti dalam Suhermanto et al. (2011), penurunan sel limfosit dipengaruhi adanya antigen asing sehingga zat kebal terganggu oleh masuknya infeksi patogen.

Persentase limfosit tertinggi ada pada P3 ( $3 \mathrm{~mL} / \mathrm{kg}$ pakan). Hal ini dikarenakan dosis larutan daun kersen mampu meningkatkan respon imun spesifik sel limfosit dalam ikan uji terhadap infeksi E.tarda. Peningkatan persentase limfosit ini disebabkan karena adanya senyawa aktif yang berperan yaitu flavonoid, fenol dan alkaloid.

Berdasarkan Tabel 1, diketahui bahwa terjadi fluktuasi persentase neutrofil ikan jambal siam, dimana pada awal pemeliharaan persentase berkisar $12,33-14,00 \%$, pada 30 hari pemeliharaan menjadi $9,33-15,33 \%$, dan pada hari ke 46 pemeliharaan persentase neutrofil ikan patin siam berkisar 8,00$17,33 \%$.

Rerata hasil persentase neutrofil pada hari ke 46 terjadi fluktuasi di beberapa perlakuan. Pada perlakuan P1 dan P2 nilai neutrofil mengalami peningkatan sebesar $13,33 \%$ dan 10,33 pasca infeksi E. tarda, nilai neutrofil ini masi dalam kategori normal.Hasil uji statistik analisis variasi (ANAVA), menunjukkan bahwa setelah 46 hari pemeliharaan dengan pemberian pakan yang ditambah larutan daun kersen memberikan pengaruh nyata terhadapat persentase neutrofil ikan jambal siam $(\mathrm{P}<0,05)$. Hasil uji lanjut Newman-Keuls menunjukkan bahwa Kp berbeda nyata terhadap Kn, P1, dan P3. P2 tidak berbeda nyata terhadap Kn, P1 dan P3.

Persentase neutrofil pada perlakuan P1 dan P2 terjadi fluktuasi yang tidak begitu tinggi dengan hasil pengamatan sebelum uji tantang, dikarenakan sel neutrofil masih bekerja dalam proses menekan infeksi bakteri yang terjadi. Neutrofil mempunyai kemampuan untuk melakukan fagositosis dan merupakan salah komponen pertahanan non spesidik yang lebih aktif dahulu (Lukistyowati, 2011). Pada infeksi akut ataupun infeksi bakteri, sel neutrofil berfungsi sebagau sel fagositik, satu sel neutrofil dapat memfagosit 5-20 bakteri. Sebelum sel neutrofil itu menjadi tidak aktif dan mati (Fujaya, 2004).

Penurunan persentase nilai neutrofil terendah terjadi pada $\mathrm{P} 3(3 \mathrm{~mL} / \mathrm{kg}$ pakan). Dimana persentase neutrofil berada pada kisaran jumlah neutrofil ikan normal, yakni sebesar $8,00 \%$. Hal ini menunjukan bahwa dosis larutan daun kersen sebanyak $3 \mathrm{ml}$ sudah cukup efektif untuk menghambat infeksi patogen, ditandai dengan penurunan persentase neutrofil. Hal ini didukung karena adanya senyawa tanin. Menurut Priyanto (2012), menyatakan senyawa tannin akan berikatan dengan membran sel dan protein ekstrakseluler pada bakteri, sehingga dapat menghambat pertumbuhan mikroorganisme atau aktifitas enzim: penurunan neutrophil terjadi karena terjadinya autolisis setelah 
berhasil menekan infeksi dari pathogen yang masuk kedalam tubuh ikan (Rustikawati 2012). Serta alkaloid yang bersifat toksit terhadap mikroba, sehingga efektif meningkatkan kerja neutrofil membunuh bakteri (Sari, 2008). Penurunan jumlah neutrofil ke arah neutrofil normal menunjukkan kondisi ikan sudah membaik.

Monosit ikan jambal siam diawal pemeliharaan berkisar 13,67-15,00\%. Lalu terjadi fluktuasi hingga hari ke 46 pemeliharaan, persentase monosit ikan jambal siam berkisar 9,00-13,67\%. Hasil uji statistik analisis variasi (ANAVA), menunjukkan bahwa setelah 46 hari pemeliharaan dengan pemberian pakan yang ditambah larutan daun kersen memberikan pengaruh nyata terhadapat persentase monosit ikan jambal siam $(\mathrm{P}<0,05)$. Hasil uji lanjut Newman-Keuls menunjukkan bahwa $\mathrm{Kp}$ berbeda nyata terhadap $\mathrm{Kn}, \mathrm{P} 1, \mathrm{P} 2$ dan $\mathrm{P}$, tetapi Kn tidak berbeda nyata dengan P1, P2 dan P3.

Penurunan persentase monosit pada ikan jambal siam mengindikasikan bahwa monosit telah berhasil mencegah terjadinya infeksi patogen. Menurut Hartika (2014), penurunan nilai monosit disebabkan karena ikan dalam kondisi sehat atau kondisi ikan yang semakin membaik setelah adanya serangan dari mikroba atau benda-benda asing, karena monositnya aktif dalam memfagosit mikroba benda asing dan juga sistem imun tubuh kuat sehingga dapat mencegah terjadinya infeksi

Selain itu, keberadaan senyawa aktif dalam larutan daun Kersen ikut berperan dalam menekan terjadinya infeksi bakteri, senyawa aktif tersebut adalah flavonoid, tanin dan saponin, sehingga membantu kerja monosit. Flavonoid berfungsi sebagai antimikroba, antivirus, dan immunostimulan (Naiborhu, 2002).

\subsection{Aktivitas Fagositosis}

Aktivitas fagositosis ikan jambal siam pasca uji tantang dengan E.tarda di hari ke-46 berkisar 24,33-21,67\%, dimana yang terendah pada perlakuan $\mathrm{Kn}$, yaitu $24,33 \%$, dan tertinggi pada pelakuan $\mathrm{P}_{3}$, yaitu $31,67 \%$. Pada semua perlakuan menunjukkan peningkatan jumlah sel yang melakukan aktivitas fagositosis. Pengamatan aktivitas fagositosis leukosit ikan jambal siam selama penelitian dapat dilihat pada Tabel 2 .

Tabel 2. Aktivitas Fagositosis (\%) pada Ikan Jambal Siam Selama Pemeliharaan

\begin{tabular}{cccc}
\hline Perlakuan & \multicolumn{3}{c}{ Persentase Sel Fagositosis (\%) } \\
\cline { 2 - 4 } & $\begin{array}{c}\text { Awal } \\
\text { pemeliharaan }\end{array}$ & $\begin{array}{c}\text { Setelah perlakuan } \\
\text { (Hari ke-30 hari) }\end{array}$ & $\begin{array}{c}\text { Pasca Uji tantang (Hari ke-46 } \\
\text { Pasca ujitantang) }\end{array}$ \\
\hline Kn & 23,00 & $24,00 \pm 1,00^{\text {ab }}$ & $24,33 \pm 0,57^{\mathrm{a}}$ \\
Kp & 21,00 & $22,67 \pm 1,52^{\mathrm{a}}$ & $25,33 \pm 2,08^{\mathrm{a}}$ \\
$\mathbf{P}_{\mathbf{1}}$ & 20,67 & $23,33 \pm 1,52^{\mathrm{ab}}$ & $25,67 \pm 1,52^{\mathrm{a}}$ \\
$\mathbf{P}_{\mathbf{2}}$ & 20,67 & $26,00 \pm 1,00^{\mathrm{bc}}$ & $30,00 \pm 1,00^{\mathrm{b}}$ \\
$\mathbf{P}_{\mathbf{3}}$ & 22,67 & $27,00 \pm 1,00^{\mathrm{c}}$ & $31,67 \pm 0,57^{\mathrm{b}}$ \\
\hline
\end{tabular}

Hasil uji statistik analisis variansi (ANAVA) menunjukkan setelah 46 hari pemeliharaan dengan pemberian pakan yang ditambah larutan daun kersen memberikan pengaruh nyata terhadapat persentase rerata fagositosis ikan ikan jambal siam $(\mathrm{P}<0,05)$. Rerata indeks fagositosis terbaik terdapat pada perlakuan P3. Hasil uji lanjut Newman-Keuls menunjukkan bahwa P3 berbeda nyata terhadap Kn, Kp, dan P1 tetapi tidak terhadap P2.

Hasil penelitian ini juga memperlihatkan bahwa aktivitas fagositosis semakin meningkat sejalan dengan meningkatnya dosis larutan daun kersen yang ditambahkan, hal ini menunjukkan bahwa telah terbentuknya sistem pertahanan tubuh pada ikan jambal siam. Menurut Utami et al. (2013) meningkatnya aktivitas sel fagosit dari darah menunjukkan bahwa sistem kekebalan atau pertahan tubuh dari ikan juga meningkat. Hal ini karena senyawa flavonoid berpotensi bekerja terhadap limfokin yang dihasilkan oleh sel $\mathrm{T}$ sehingga merangsang sel-sel fagosit untuk melakukan respon fagositosis (Nugroho, 2012).

\subsection{Kelulushidupan Ikan Jambal Siam}

Kelulushidupan ikan jambal siam yang dipelihara selama 46 hari dengan diberi pakan yang ditambah larutan daun kersen dapat dilihat pada Gambar 3. 


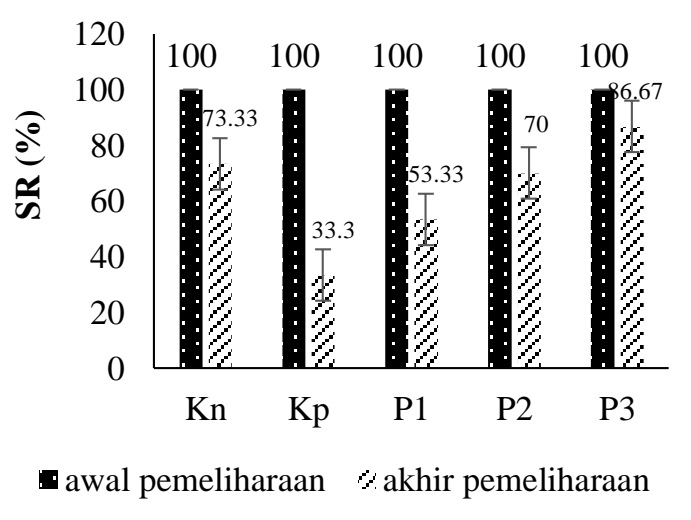

Gambar 3. Tingkat Kelulushidupan Ikan

Gambar 3 menunjukkan bahwa persentase kelangsungan hidup tertinggi terdapat pada perlakuan P3 (3 $\mathrm{mL} / \mathrm{kg}$ pakan) yaitu sebesar $86,67 \%$, kemudian diikuti oleh perlakuan P2 (2 mL/kg pakan) yaitu sebesar 70\%, P1 (1 mL/kg pakan) sebesar 53,33\%, dan Kn (pemberian pakan tanpa penambahan kersen dan tidak di uji tantang dengan E.tarda) sebesar 73,33\%, dan terendah pada perlakuan $\mathrm{Kp}$ (pemberian pakan tanpa penambahan larutan kersen dan di uji tantang dengan E.tarda) sebesar 33,33\%.

Kelulushidupan pada perlakuan Kp lebih rendah dikarenakan tidak ada penambahan larutan kersen dalam pakan sehingga pada pasca infeksi dengan bakteri E. tarda, bakteri terus berkembang sehingga mampu menghasilkan gejala klinis yang lebih parah, ikan uji yang ketahanan tubuhnya lemah akan mengalami kematian.

Untuk perlakuan P2 dan P3 memiliki sistem pertahanan tubuh non spesifik yang lebih baik. Hal ini memperlihatkan kandungan bahan antibakterial yang terdapat pada konsentrasi tersebut sudah efektif untuk mecegah dari infeksi E. tarda. Flavonoid, tanin, saponin serta alkaloid yang terkandung dalam daun kersen mampu mencegah adanya inflamasi ekternal maupun internal karena senyawa-senyawa tersebut bersifat antibakteri, antiinflamasi, dan imunostimulan. Komponenkomponen ini membentuk senyawa kompleks terhadap protein extraseluler yang mengganggu keutuhan membran sel bakteri dengan cara mendenaturasi protein sel bakteri dan merusak membran sel tanpa dapat diperbaiki lagi (Juliantina, 2008).

\section{Kesimpulan dan Saran}

Berdasarkan hasil penelitian dapat disimpulkan bahwa ada pengaruh penambahan larutan daun kersen dalam pakan terhadap gambaran leukosit ikan jambal siam dilihat dari adanya peningkatan total leukosit, diferensiasi leukosit, dan aktivitas fagositosis $(\mathrm{P}<0,05)$. Dosis terbaik terdapat pada perlakuan P3 (3 mL larutan kersen/ kg pakan) dengan rata-rata total leukosit sebesar 9,38 x $10^{4} \mathrm{sel} / \mathrm{mm}^{3}$, limfosit sebesar $83,00 \%$, neutrofil sebesar $8,00 \%$, monosit sebesar $9,00 \%$, nilai indeks fagositosis sebesar $31,67 \%$, dan kelangsungan hidup sebesar $86,67 \%$.

Berdasarkan hasil penelitian dapat disarankan perlunya dilakukan penelitian lanjutan untuk melihat gambaran histopatologi ikan jambal siam yang terinfeksi bakteri E. tarda yang diberi pakan yang mengandung larutan daun kersen.

\section{Daftar Pustaka}

[KKP] Kementrian Kelautan dan Perikanan. (2018). Kelautan dan perikanan dalam Angka. $2018 . \quad$ Jakarta. http://www.kkp.go.id [20 Desember 2018]

Ajizah, A. (2004). Sensitivitas Salmonella typhymurium terhadap Ekstrak Daun Jambu Biji (Psidium guajava L.). Journal of Bioscientiae, 1(1): 31-38.

Andriyanto, S. (2009). Deteksi Edwardsiella tarda secara imunohistokimia pada ikan jambal siam (Pangasius pangasius). Majalah Ilmu Kehewanan Indonesia.

Darsana, I. G. O., I. N. K. Besung dan H. Mahatmi. (2012). Potensi Daun Binahong (Anredera Cordifolia (Tenore) Steenis) dalam Menghambat Pertumbuhan Bakteri Escherichia coli secara In Vitro. Indonesia Medicus Veterinus, 1(3): 337-351

Dontriska, A.D. Sasanti, Yusliman. (2014) Efektivitas Tepung Jintan Hitam (Nigella sativa) untuk Mencegah Infeksi Aeromonas hydropilla pada Ikan Patin Jurnal Akuakultur Rawa Indonesia, 2 (2) : 188-201

Fujaya, Y. (2004). Fisiologi Ikan Dasar Pengembangan Teknik Perikanan. Rineka Cipta. Jakarta. 179 hlm

Haki, M. (2009). Efek Ekstrak Daun Talok (Muntingia calabura L.) terhadap 
Aktivitas Enzim SGPT pada Mencit yang diinduksi Karbon Tetraklorida. Fakultas Kedokteran, Universitas Sebelas Maret. Surakarta.

Hartika, R., Mustahal, dan Putra A.N. (2014). Gambaran Darah Ikan Nila (Oreochromis niloticus) dengan Penambahan Dosis Prebiotik yang Berbeda dalam Pakan. Jurnal Perikanan dan Kelautan, 4(4): 259-267.

Jhonny, F., D.Roza, K. Mahardika, Zafran dan A. Prijono. (2005). Penggunaan Imunostimulan untuk meningkatkan kekebalan non-spesifik benih kerapu lumpur (Ephinephelus coioides) terhadap infeksi virus Vibrio. Jurnal Penelitian Perikanan Indonesia, 11(5):75-84

Juliantina, F.R. (2008). Manfaat Sirih Merah (Piper crocatum) Sebagai Agen Antibakteri terhadap Bakteri Gram Positif dan Gram Negatif. Jurnal Kedokteran dan Kesehatan Indonesia. 1(1): 345

Linder, M.C. (1992). Biokimia Nutrisi dan Metabolisme. Parakkasi A. Terjemahan dari: National Biochemistry and Metabolism. Penerbit Universitas Indonesia, Jakarta.

Lukistyowati, I. (2011). Efektivitas Bawang Putih (Allium sativum) untuk Meningkatkan Ketahanan Tubuh Ikan Mas (Cyprinus carpio) Terhadap Penyakit Aeromonas septicemia. Disertasi. Universitas Gadjah Mada. Yongyakarta. $242 \mathrm{hlm}$

Pangestika, D., M. Erna., Mashoedi., Imam D.(2012). Pengaruh Pemberian Kunyit (Curcuma domestica Val.) Terhadap Aktivitas Fagositosis Makrofag pada Mencit BALB/C yang Diinokulasi Bakteri Listeria Monocytogenes. Skripsi. Fakultas Kedokteran. Unissula Semarang.

Preanger, C., I.H. Utama, I.M. Kardena. (2016). Gambaran Ulas Darah Ikan Lele di Denpasar Bali. Fakultas Kedokteran Hewan. Universitas Udayana. Indonesia Medicus Veterinus, 5(2): 96-103.
Priyanto R. A. (2012). Aktivitas Antioksi dan Komponen Bioaktif pada Buah Bakau (Rhizophora mucronata). Skripsi. Institut Pertanian Bogor. Bogor.

Robinson, T. (1995). Kandungan Organik Tumbuhan Tinggi, Edisi VI: 191- 216,

Diterjemahkan oleh Kosasih Padmawinata, ITB, Bandung

Rosidah, L.W., Iskandar, Afpriliansyah, M.R. (2018). Efektivitas Ekstrak Daun Kersen untuk Pengobatan Benih Ikan Nila yang Terinfeksi Bakteri Aeromonas hydrophila. Jurnal Akuatika Indonesia, 3(1):10-18.

Sari, D.K. (2008). Penapisan Antibakteri dan Inhibitor Topoisomerase I dari Xylocarpus granatum. Tesis. ITB. Bogor. $78 \mathrm{hlm}$.

Suhermanto, A., S. Andayani dan Maftuch. (2011). Pemberian Total Fenol Teripang Pasir (Holothuria scabra) untuk Meningkatkan Leukosit dan Diferensial Leukosit Ikan Mas (Cyprinus carpio) yang diinfeksi Bakteri Aeromonas hydrophila. Jurnal Kelautan, 4 (2) : 49-56.

Sukenda., S.L. Jamal., D. Wahjuningrum., A. Hasan., 2008. Penggunaan Kitosan Untuk Pencegahan Infeksi Aeromonas hydrophila pada Ikan Lele Dumbo Clarias sp. Jurnal Akuakultur Indonesia, 7(2): 159-169.

Thune, R.L., Stanley, L.A., dan Couper, R.K. (1993). Pathogenesis of Gram-negative Bacterial Infection in Warm Water Fish. Annu. Rev. Fish. Dis., 3: 37-68.

Utami, W.P. (2009). Efektifitas Ekstrak Paci Paci (Leucas lavandulaefolia) yang Diberikan Lewat Pakan untuk Pencegahan dan Pengobatan Penyakit Motile Aeromonas Septicemia pada Ikan Lele Dumbo Clarias sp. Skripsi. Departemen Budidaya Perairan. Fakultas Perikanan dan Ilmu Kelautan Institut Pertanian Bogor.

Zebua, R.D., H, Syawal., I, Lukistyowati. (2019). Pemanfaatan Ekstrak Daun Kersen (Muntingia calabura L) untuk Menghambat Pertumbuhan Bakteri Edwardsiella tarda. Jurnal Ruaya. 7 